JURNAL AL BAYAN: JURNAL JURUSAN PENDIDIKAN BAHASA ARAB

p-ISSN 2086-9282 | e-ISSN 2549-1229

http://ejournal.radenintan.ac.id/index.php/albayan/index

\title{
Needs Analysis of Arabic Guided Writing Material Using Task-Based Learning
}

\author{
Muhammad Kamal bin Abdul Hakim
}

Arabic Education Study Program Universitas Negeri Jakarta, Indonesia

Article History:

Received : September 02, 2019

Revised : October 05, 2019

Accepted : November 03, 2019

Published : December 01, 2019

Keywords:

Participant; Practice; Students;

Teacher

*Correspondence Address:

m.kamal.ah@unj.ac.id

\begin{abstract}
Writing is not only as academic skills but also it as as important skills to facilitate the career and life needs. Writing material must be designed to realize the skills that are directly implemented in daily life. Therefore, the needs analysis process is a necessity to find out those needs. The aim of study was to get the students' needs of Arabic guided writing material through task-based learning. Writing has to create as task learning because it needs more practice. This study needs to design guided material. The research used qualitative research using descriptive qualitative method. The process of collecting data used documentation, interview and questionnaire. Data analysis used descriptive qualitative technique and judgment experts. The result of finding show that teacher and students need authentic material refers to practice. Task-based learning has offered the variation of task. Almost the participant answered that the types of task is available with the Arabic guided writing learning. This study is not oriented to the writing material content but also combined with the variation task activity. It can be implemented in guided writing subject. The consortium is able to develop in the material arranging.
\end{abstract}

\section{Introduction}

Writing has a very big role in human life as a medium to explore knowledge space and time. Human daily activities are inseparable from writing activities. But writing in a foreign language such as Arabic, especially for students, is still considered very difficult. This is due to the ability of Arabic language not used in daily activities. Thus, the guided learning process of Arabic writing requires a very precise design of materials and in accordance with the needs of students. Thus, the material is given must also be adjusted to the level of the easiest to most difficult. In addition, writing materials must also be adapted to global needs, so that the writing ability obtained by students in class can be implemented in daily life such as for work matters. 
Material has a very important role in the learning process. Especially in learning Arabic that has unique and different language characters compared to other foreign languages. Learning process using materials of similarities and differences is not taught in a complicated and complex manner. But as an initial concept to let the students use this tool when finding any similarity and difference during their Arabic learning. Learning vocabularies will be more productive if they place vocabularies in complete sentences. ${ }^{1}$ At present, teaching materials provided by teachers are very easy to obtain through the use of technology. Many electronic books in foreign languages can be downloaded. In addition, teaching materials can also be presented not only through books, but in the form of CDs, Videos and so on. This makes the learning process easier and more enjoyable.

Like as in guide writing learning always need authentic material because the students need imagination in learning. Writing is one of the skills in Arabic language learning that viewed as most difficult learning. It provides many aspects like as grammatical, contexts, mechanism, and others. Thus, teacher has to design the material available with the guide writing content. Tomlinson stated that "Materials design begins by identifying a gap, a need for material because the existing coursebook fails to meet a learning outcome of the course or because the students need further practice in a particular aspect writing. They then state that the teacher needs to explore this area to gain a better understanding of the particular skill or feature involved, perhaps consulting reference materials, corpora, colleagues, specialist informants, text models or other sources......". The textbook/course materials are one of the important factors that influence the learners' motivation in learning. If the learning materials are improperly prepared, it may negatively affect the learners' motivation to continue to learn Arabic. Thus, teachers, syllabus and course designers have to put efforts to design and develop attractive and innovative course materials.

Therefore, teachers can design their own material according to the needs and characteristics of the University and students. This is easy to do because of technological advancements. Source of material that can be obtained through internet access. Many

\footnotetext{
${ }^{1}$ Ismail Suardi Wekke, "Arabic Learning Material of Higher Education Muslim Community North Sulawesi," Dinamika Ilmu 17, no. 2 (December 4, 2017): 175-189, accessed March 31, 2019, https://journal.iain-samarinda.ac.id/index.php/dinamika_ilmu/article/view/863.

${ }_{2}^{2}$ Brian Tomlinson, Developing Materials For Language Teaching Second Edition (New York: Bloomsbury, 2013).
} 
learning sites of Arabic writing or other foreign languages that can access, so that students can work at any time because learning to write requires a lot of practice. Nasir, et.al., concluded that guidelines to the teachers as to which pedagogies should they adopt to improve their students' creative writing skills. It would be enjoyable and beneficial for those teachers who have direct contact with the students and they would be excited to witness a change. ${ }^{3}$

The result of observation concluded that the Arabic guide writing problem is; 1) variation of material is less, 2) the material is not appropriate with the students' needs and characteristics, 3) source of learning (textbook) is less, 4) students do not get teacher's feedback, 5) time on work is limited, and 6) learning strategies that are less supportive of students practising writing. Therefore, the provision of teaching materials as the main material in the learning process becomes very necessary. In the Arabic Language Study Program, Jakarta State University for guided writing courses has not been designed according to the needs of students and globally, so the level of failure to pass this course reaches $60 \%$. The percentage is considered very high. From the results of interviews with students, it was concluded that the concept of the material being taught was not in accordance with the needs and characteristics of the learning objectives.

However, the study must be done to get the appropriate material in Arabic guided writing learning. The lecture can investigate the students' needs of Arabic guided writing using needs analysis. Yundayani, et.al. investigated instructional material should be designed based on students' needs. The studied show that the material provided language content for academic purposes. ${ }^{4}$ Sabarun concluded that internet-based materials are preferred for developing EFL writing materials. The materials should be made excellent integration of resources available on the web. ${ }^{5}$ Previous research show that needs analysis of teaching material referred on the content material and media of learning based. To date, there has been no research on how design needs analysis of Arabic

\footnotetext{
${ }^{3}$ Laraib Nasir, Syeda Meenoo Naqvi, and Shelina Bhamani, "Enhancing Students Creative Writing Skills: An Action Research Project," Acta Didactica Napocensia 2, no. 2 (2013).

${ }^{4}$ Audi Yundayani, Emzir Emzir, and Zainal Rafli, "NEED ANALYSIS: THE WRITING SKILL INSTRUCTIONAL MATERIAL CONTEXT FOR ACADEMIC PURPOSES,” English Review: Journal of English Education 6, no. 1 (December 23, 2017): 59, accessed December 6, 2019, https://journal.uniku.ac.id/index.php/ERJEE/article/view/771.

5 . Sabarun, "Needs Analysis on Developing EFL Paragraph Writing Materials at Kalimantan L2 Learners," English Language Teaching 12, no. 1 (December 24, 2018): 186, accessed December 6, 2019, http://www.ccsenet.org/journal/index.php/elt/article/view/0/37905.
} 
guided writing using task context and it is relevant with Arabic context. Task refers to task-based learning. In writing learning needs more practice.

Writing learning can involve digital facilities so that students feel more fun. Writing digital school texts thus becomes a literacy project in communication ecology with various levels of collaborative writing. Collaborative learning is one of the tasks that helps students who are weak to write can write well. ${ }^{6}$ The pedagogical benefits of taskbased teaching of EFL are numerous. The task-based approach has blocked the distance between class and real-life and has altered the malpractice in which teachers totally isolated traditional foreign language teaching from real life. Arabic language has shortcomings, weaknesses, and deficiencies at the level of phonemes, words, structures, texts, and general contexts that are broadened from the educational curriculum in schools and universities, making it difficult to understand. It is especially in learning to write. ${ }^{7}$ The production of quality and various reading Arabic texts is important in teaching and learning of Arabic as a second language. This is because it serves as a basic reference in Arabic curriculum in Therefore, the parties involved in the drafting of the text books in particular, must play an important role to produce writing that is creative and relevant to current needs for quality of production will shape thinking among readers, particularly students who are learning Arabic as a second language. ${ }^{8}$

Youn concluded that the majority of students expressed their need to communicate with a professor and culture-specific written genre. Low-level students expressed stronger pragmatic learning needs and high-level students expressed real interest in understanding the professor's cultural jokes and implied meaning. Triangulating various stakeholder opinions allows getting various perspectives on taskbased pragmatic needs in the EAP context. Further findings are discussed in terms of how they inform the development of meaningful pragmatic EAP tasks. ${ }^{9}$ Hismanoglu \& Hismanoglu stated that the growing popularity of Task-Based Language Teaching

\footnotetext{
${ }^{6}$ Marie Nordmark, "Writing Roles: A Model for Understanding Students' Digital Writing and the Positions That They Adopt as Writers," Computers and Composition 46 (December 1, 2017): 56-71, accessed August 29, 2018, https://www.sciencedirect.com/science/article/abs/pii/S8755461516300639.

7 Basma Ahmad Sedki Dajani, "Teaching Arabic Language: Towards a New Beginning That Stimulates Creativity,” Procedia - Social and Behavioral Sciences 192 (June 24, 2015): 758-763, accessed May 31, 2018, https://www.sciencedirect.com/science/article/pii/S1877042815035570.

${ }^{8}$ Aisah Hasmam and Nik Mohd Rahimi, "Types of Text in Books for Learning Arabic as a Second Language: A Document Analysis," Procedia - Social and Behavioral Sciences 7 (January 1, 2010): 50-56, accessed June 14, 2019, https://www.sciencedirect.com/science/article/pii/S1877042810020124.
} 
(TBLT), identifying target tasks through needs analysis (NA), which is an integral part of the approach, is often skipped by teaching professionals and curriculum designers, potentially obscuring the benefits TBLT can offer. The authentic materials begin with the need analysis. It gives information about students' want, needs, and lack in learning. ${ }^{10} \mathrm{~A}$ needs analysis survey was conducted among law students their hopes, desires and needs generally indicate that students have high motivation to attend English classes. ${ }^{11}$ The present investigation highlights the importance of NA for curriculum construction, calling for more frequent and systematic implementation of NA in the field. ${ }^{12}$ Therefore, the main problem this study is 'how is the needs analysis of Arabic guided writing material through task-based learning model?"

\section{Theoretical Support}

\section{Needs Analysis}

In general, needs analysis (called needs assessment) is an activity that involves the process of gathering information. It is used as a basis for curriculum development to meet the learning of certain groups of students. According to Nation and Macalister, needs analysis is information about what things are known or learned by students and what things need to be known or needed by students. Needs analysis is directly related to learning objectives and content. The results of the needs analysis will show that learning must contain things are relevant and beneficial to students. ${ }^{13}$ Brindley offers other dichotomies related to the type of information in needs analysis, namely objective needs and subjective needs. Objective needs are needs that are determined on the basis of gathering information about the situation, students and language. Students must obtain, skills and skill levels, and so on. From this analysis can be obtained situation information

\footnotetext{
${ }^{9}$ Soo Jung Youn, "Task-Based Needs Analysis of L2 Pragmatics in an EAP Context," Journal of English for Academic Purposes 36 (November 1, 2018): 86-98, accessed June 2, 2019, https://www.sciencedirect.com/science/article/pii/S147515851830184X.

${ }^{10}$ Murat Hismanoglu and Sibel Hismanoglu, "Task-Based Language Teaching: What Every EFL Teacher Should Do," Procedia - Social and Behavioral Sciences 15 (January 1, 2011): 46-52, accessed June 14, 2019, https://www.sciencedirect.com/science/article/pii/S187704281100228X.

11 Barbora Chovancová, "NEEDS ANALYSIS AND ESP COURSE DESIGN: SELFPERCEPTION OF LANGUAGE NEEDS AMONG PRE-SERVICE STUDENTS," STUDIES IN LOGIC, GRAMMAR AND RHETORIC $38 \quad 38$, no. $51 \quad$ (2014), accessed April 11, 2018, https://www.degruyter.com/downloadpdf/j/slgr.2014.38.issue-1/slgr-2014-0031/slgr-2014-0031.pdf.

12 Takehiro Iizuka, "Task-Based Needs Analysis: Identifying Communicative Needs for Study Abroad Students in Japan," System 80 (February 1, 2019): 134-142, accessed December 6, 2019, https://www.sciencedirect.com/science/article/abs/pii/S0346251X18302021.

13 I.S.P. Nation and John Macalister, Language Curriculum Design (New York dan London: Routledge Taylor \& Francis Group, 2010).
} 
and are useful for integrating desires in developing. In other words, the results of the information can assist researchers in analyzing and adjusting the development needs. In addition, subjective needs are generally determined through gathering information from aspects of wants, desire, and expectation. ${ }^{14}$ In fact, Brindley in Richards's book also states that the term subjective needs sometimes refer to wants, desires, demands, expectations, motivations, lacks, constraints, and requirements. ${ }^{15}$

Hutchinson and Waters divide the needs into two, first is the target needs related to what students need to do something in the target situation, second is the learning needs related to what ways students can learn. ${ }^{16}$ Analysis of target needs consists of: (1) Necessities, i.e. needs which are determined by the demand of the target situation. In this case, it related to what students must master in order to function effectively with the target language. (2) Weaknesses (Lacks), which are related to what students should have mastered but have not actually obtained by students. In this case, the shortage is the gap between expectations and the real conditions that exist in students. (3) Desires (Wants)is related to the views and expectations of students from learning the target language. ${ }^{17}$

\section{Guide Writing}

Guide writing is the writing process that is related to the teacher. According to Hamp-Lyons \& Kroll, writing is an activity that occurs based on the context, to get the goal, and provide written form aimed at the reader. Sperling explained that writing is like language in general, which means carrying out activities socially and culturally as well as individual and social goals. In developing the social nature of writing, Hayes stated "(Writing) is also social because it is a social artefact and is carried out in a social setting. What we write, how we write, and who we write to is shaped by social convention and by our history of social interaction... The genre in which we write was invented by other writers and the phases we write often reflect phrases earlier writers have written. ${ }^{18}$

In the process of language teaching, it can determine whether the focus is on writing products or the writing process itself. When focusing on products, we are only interested in goals and results. The approach that is widely used in teaching writing is

${ }^{14}$ James Dean Brown, The Element of Language Curriculum A Systematic Aproach to Program Development (Massachusetts: Heinle \& Heinle Publisher, 1995).

15 Jack C. Richards, Curriculum Development in Language Teaching (United State of America: Cambridge University Press., 2001).

${ }^{16}$ Nation and Macalister, Language Curriculum Design.

17 Tom Hutchinson and Alan Waters, English for Spesific Purposes (Cambridge: Cambridge University Press, 1991). 
more focused on the product (product approach) rather than the writing process itself. In reality, the writing process is more complex and has several steps such as drafting, reviewing, re-drafting and writing, and so on. ${ }^{19}$ According to Sokolik, writing is a combination of activities between processes and products. Olson described the process as referring to the unification of ideas from beginning to end and becoming an article ready to be published, this process is useful for novice writers. Because writing has many steps, not just based on the logic that evokes a different imagination. ${ }^{20}$ Writing is a physical activity because there are processes and products produced. The activities of this process will go through several stages such as determining ideas, developing ideas into writing, reviewing, and editing.

\section{Material}

Material is what the teacher uses, techniques and activities are how the teacher uses it. For teachers who design learning, material development means creating, selecting or adapting, and managing material and carrying out activities. Then Students can achieve goals that will help them find learning goals. The material developed is influenced by beliefs and understanding of the teaching and learning process of language as applied to learn based on context. ${ }^{21}$ Shulman stated that the key to understanding the knowledge base of teaching lies at the interaction of content a pedagogy. In the capacity of a teacher to transform the content knowledge, he or she possesses into forms that are pedagogically powerful and yet adaptive to the variations in ability and background presented by students. ${ }^{22}$ Cunningsworth described the evaluation criteria of materials in textbook using some categories, these are aims and approaches, design and organization, language content, skills, topic, methodology, teacher's books, and practical consideration. ${ }^{23}$

In developing the material, things that need to be considered in a language program, both the advantages and disadvantages of the material development project must pay attention to the basics first. Components of strengths in compiling material development in language programs include: relevant, expert development, reputation,

\footnotetext{
${ }^{18}$ Sara Cushing Weigle, Assessing Writing (United Kingdom: Cambridge University Press, 2002).

19 "Jeremy Harmer-The Practice of English Language Teaching with DVD (4th Edition) (Longman Handbooks for Language Teachers)-Pearson Longman ELT (2007).Pdf,"

${ }^{20}$ Caroline T. Linse, Practical English Language Teaching Young Learners (McGraw Hill, 2005).

${ }^{21}$ Kathleen Graves, Designing Language Course \& Guide for Teachers (Boston: Heinle and Heinle, Thomson Learning., 2000).

${ }^{22}$ Richards, Curriculum Development in Language Teaching.
} 
and flexibility. While the shortcomings that must be considered before starting to develop material include: cost, quality and training.

Some teachers use instructional material as the main source of teaching. The material prepares the basis for the content of the lesson, the equality of abilities taught, and the types of language practice undertaken by students. For students, the material provides the main resource they have by separating language from the instructor. Therefore, the role and use of the material in language programs is a significant aspect of language curriculum development.

\section{Task-Based Learning}

Task-based learning is one approach in communicative language teaching. It refers to the task as the classroom activities. Nunan stated that task-based language teaching is an approach to language teaching organized around tasks rather than language structures. ${ }^{24}$ In task-based learning, in general, the teacher as a facilitator, always takes care of the learning situation. The process of facilitating learning involves balancing a number of actions and the use of language, and determining whether they are truly quality. According to Willis that the task-based learning framework mostly emphasizes student activities, often being in groups or doing group activities, using language to achieve completed tasks and being guided by the teacher.

Meanwhile, Breen in Nunan described that the 'task' is assumed to be various work plans that aim to facilitate language learning from simple and brief types of exercises, leading to more complex and longer activities such as problem-solving groups or simulations and decision making. Then, Nunan defines communicative tasks as part of classwork that involves studentsin understanding, manipulating, producing or interacting in the target language with a focus on meaning, it is not on form. The task must also provide a sense of completeness, able to stand alone as a communicative act in itself. According to Nunan, there are elements that must be followed when designing a task, namely: goals, input, procedures, the role of the teacher, the role of students, and setting. ${ }^{25}$

Hammer argues that the component of the task-based learning framework directs teachers to follow step by step effectively in learning because task-based learning has

\footnotetext{
${ }^{23}$ Alan Cunningsworth, Choosing Your Coursebook (Heineman: Oxford, 1995).

24 David Nunan, Designing Tasks for the Communicative Classroom (Cambridge: Cambridge University Press, 2001).

25 Jane Willis, A Framework for Task-Based Learning (Italy: Addison Wesley Longman, 1996).
} 
different stages from other teaching methods. This is consistent with Willis's view in Hammer that task-based learning has a framework consisting of pre-tasks, task cycles, and language focus. ${ }^{26}$ A teacher must plan and carefully select activities at each stage of teaching because pre-assignments, task cycles, and language focus each play a direct role in obtaining student language. When the task-based learning approach is applied, the teacher must pay attention so that students' abilities can be well exposed when writing.

\section{Method}

This study used qualitative research using the descriptive qualitative method. This method describes the phenomenon to show the patterns and themes that related to the fact through specific questions. It has two approaches which are the exploratory and case study. ${ }^{27}$ Thus, this research explores teacher and student needs analysis about guide writing material through task-based learning.

\section{Participant of Research}

The participant fills the questionnaire to know the teacher and students' needs analysis. Then, the participant of the study is the teacher that taught Arabic guide writing and students is in the $3^{\text {rd }}$ semester of the 2018/2019. The location of research is Arabic Education at Jakarta State University.

\section{The process of Collecting Data}

The process of collecting data in this study are; (1) Documentation. This process is to analyze the Arabic guide writing material or textbook that has used in the Arabic Education Program Study. (2) Interviews. It is to know the students and teacher's needs in Arabic guide writing. (3) Questionnaire. It is to know the students and teacher's needs in Arabic guide writing. The researcher provides some questions that related to Arabic guide writing material.

\section{The Technique of Data Analysis}

This study used a qualitative method to analyze the data which has gotten from the questionnaire. It is descriptive qualitative form. There are three steps of data analysis, namely data reduction, data display, and taking conclusion. Besides that, the technique of data analysis used judgment expert.

${ }^{26}$ Heidi Byrnes and Rosa M. Manchon, Task-Based Language Learning Insight from and for L2 Writing (Amsterdam: John Benjamin Publishing Company, 2014). 


\section{Result and Discussion}

Needs analysis is not only done for students, but also for lecturers in Arabic writing (Kitabah). Analysis of the needs of lecturers includes; types of tasks required (input) and (content). This concept is relevant with Nation and Macalister theory that needs analysis is information about what things are known or learned by students and what things need to be known or needed by students. Needs analysis is directly related to learning objectives and content. The content is not only about writing material but also types of task will ask to students. Input is be as objectives. In the table below the answers to the needs analysis are asked through a questionnaire to Kitabah lecturers who total 2 people in developing Arabic writing teaching materials (kitabah) through Task-Based Learning (TBL) in the Arabic Language Education Study Program Faculty of Languages and Art Jakarta State University (UNJ).

The questionnaire submitted consisted of two parts; The first question concerns the subject matter needs of the teaching material with the type of task required (input) and the type of task required (content). Here is the percentage of each component;

\section{Types of the task (Input)}

Here is the result of data analysis of task needs in guide writing learning.

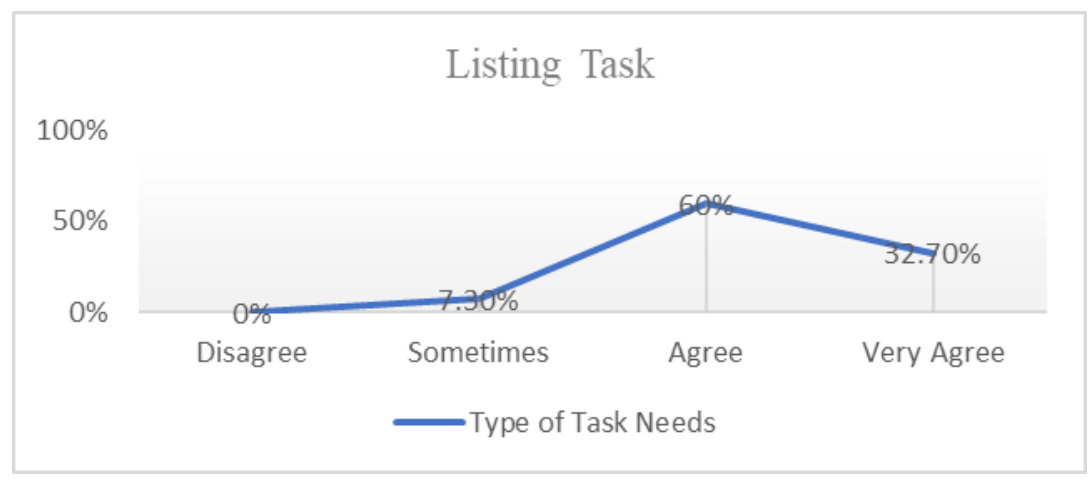

Figure 1. Listing Task Needs

Figure 1 can be seen that the students' answers about the types of the task required in the explanation of the task of making a list, it was agreed of $60 \%$, it was very agreed of $32.7 \%$, it was sometimes of $7,3 \%$ and it disagreed of $0 \%$ less. This shows that students need an explanation of the task of making a list of teaching material to be developed.

\footnotetext{
${ }^{27}$ Rosemarie Rizzo Parse, Qualitative Inquiry: The Path of Sciencing (New York: NLNs, 2001).
} 


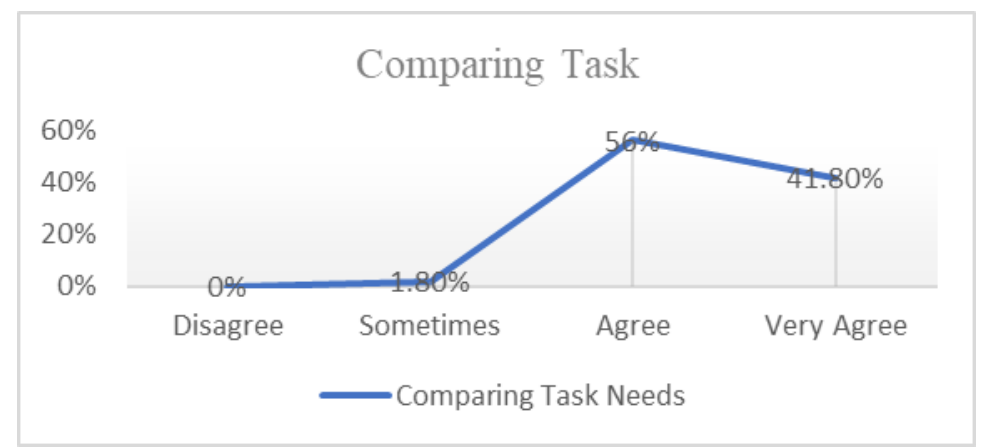

Figure 2. ComparingTask Needs

Figure 2 can be seen that the students' answers about the types of the task required in the explanation of the comparison, it was agreed of $56.4 \%, 23$ people said it was very agreed or $41.8 \%, 1$ person said it was sometimes or $1,8 \%$. This shows that students need an explanation of the comparison tasks in teaching the material to be developed.

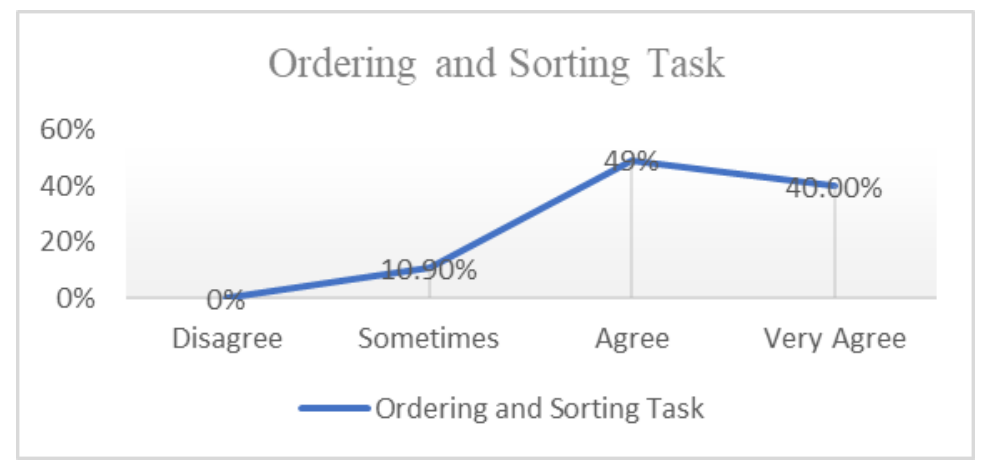

Figure 3. Ordering and Sorting Task Needs

Graph 3 can be seen that the students' answers about the types of the task required in the explanation of the ordering and sorting task, 27 people said it was agreed or $49.1 \%, 22$ people said it was very agreed or $40 \%, 6$ people said it was sometimes or $10,9 \%$. This shows that students need an explanation of the ordering and sorting in teaching material to be developed.

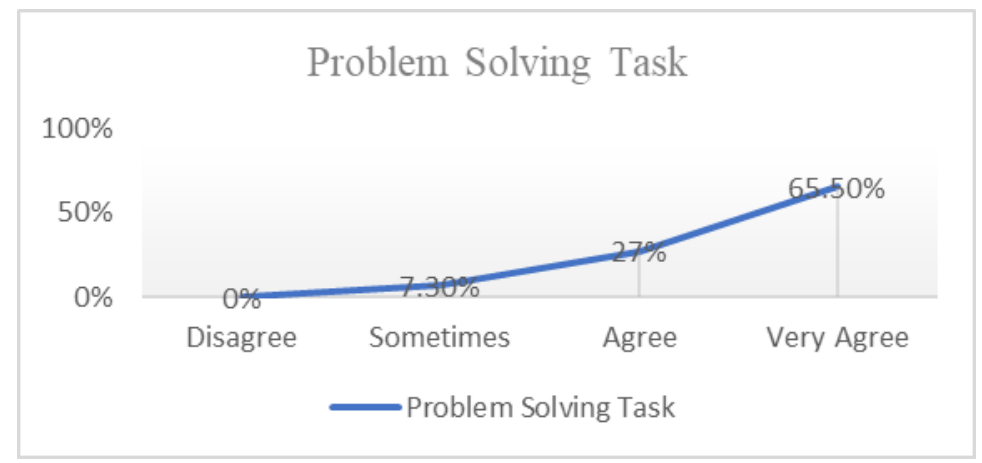

Figure 4. Problem Solving Task Needs 
Figure 4 concludes that students' answers about the types of the task required in teaching materials of problem-solving, 33 people said it was very agreed or $65.5 \%, 15$ people said it was agreed or $27.3 \%, 4$ people said it was sometimes or 7,3\%. It means that students really need an explanation of problem-solving in teaching material that will be developed.



Figure 5. Problem Solving Task Needs

Figure 5 concluded that students' answers about the types of the task required in teaching materials of sharing personal experiences, 26 people said it was very agreed or $47.3 \%, 16$ people said it was agreed or $29.1 \%, 13$ people said it was sometimes or $23.6 \%$.

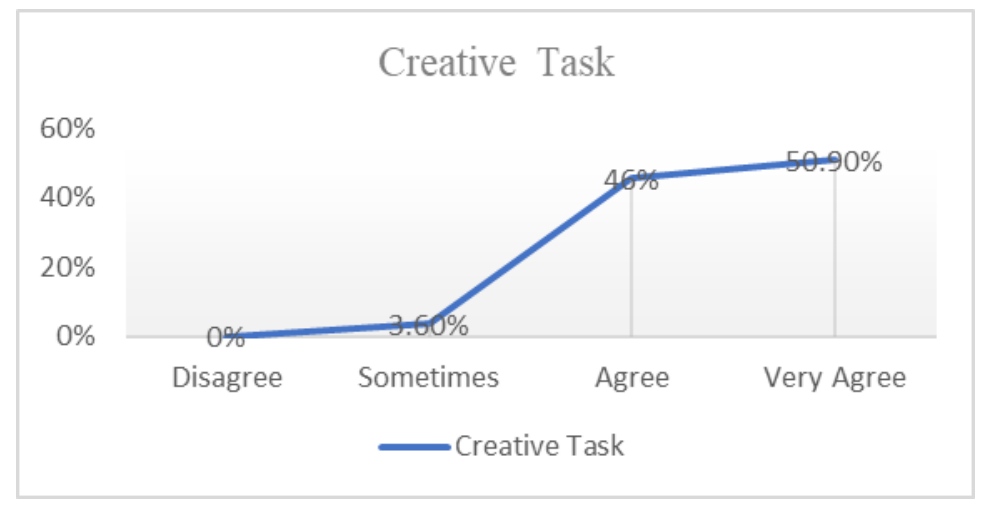

Figure 6. Creative Task Needs

Figure 6 concluded that students' answers about the types of the task required in teaching materials of creative assignments, 28 people said it was very agreed or $50.9 \%$, 25 people said it was agreed or $45.5 \%, 2$ people said it was sometimes or 3, $6 \%$.

From the graph that it has been presented each question the need for task types through input. It concluded that students have a high level of need in each category of task types presented in a questionnaire. This is evident from the dominance of student answers in the category of agreeing and strongly agree.

\section{Types of a task (Content Focus)}




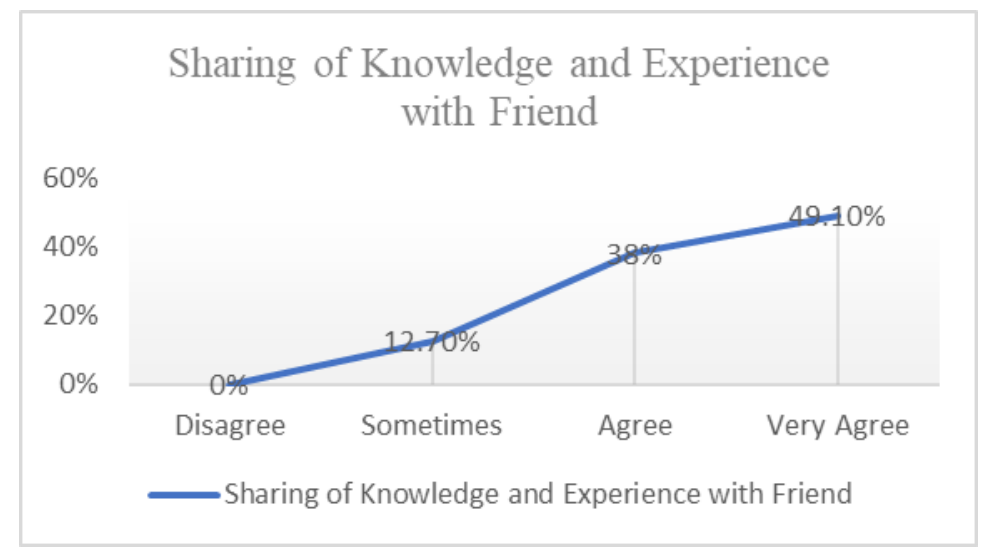

Figure 7. Sharing of Knowledge and Experience with Friend Task Needs

Graph 7 concludes that students' answers about the types of the task required in teaching materials on sharing knowledge and experience with friends, 27 people said it was very agreed or $49.1 \%, 21$ people said it was agreed or $38.2 \%, 7$ people said it was sometimes or $12.7 \%$

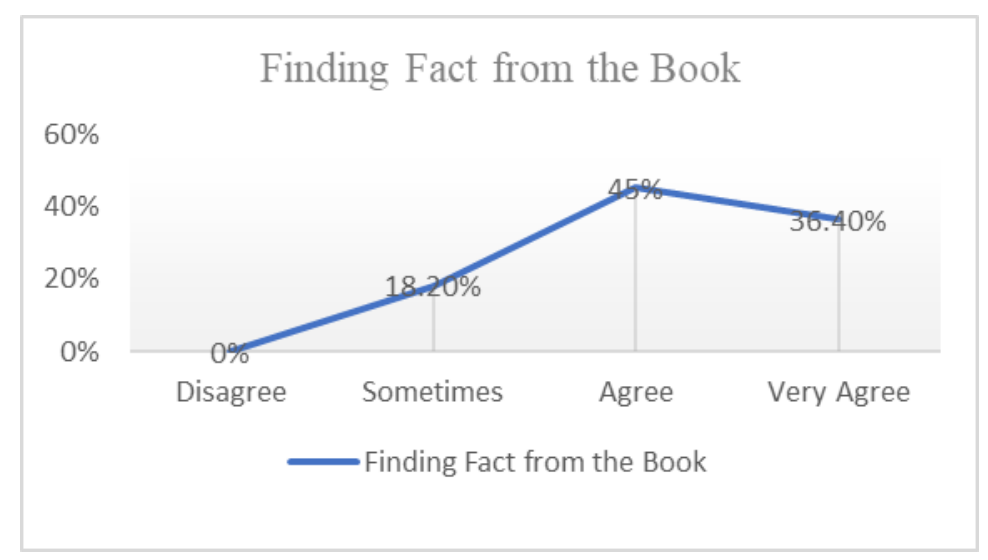

Figure 8. Finding Fact from the Book Task Needs

Figure 8 concludes that students' answers about the types of the task required in teaching materials on the task of finding facts from books, 25 people say it is agreed or $45.5 \%, 23$ people say it is very agreed or $41.8 \%, 10$ people say it is sometimes or $18,5 \%$.

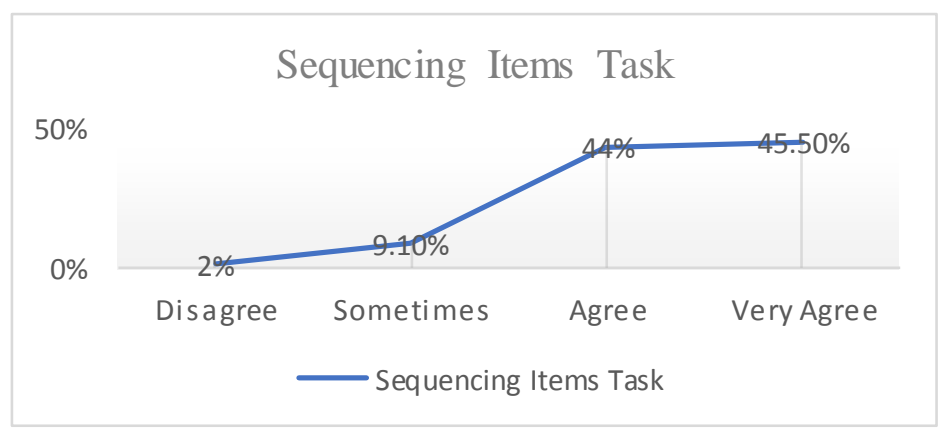


Figure 9. Sequencing Items Task Needs

Figure 9 concludes that students' answers about the types of task needed in teaching materials on assignments sort the actions or events in a logical or chronological order, 25 people say it is very agreed or $45.5 \%, 24$ people say it is agreed or $43.6 \%, 5$ people say it is sometimes or $9.1 \%$ and 1 person say it disagrees or $1.8 \%$.

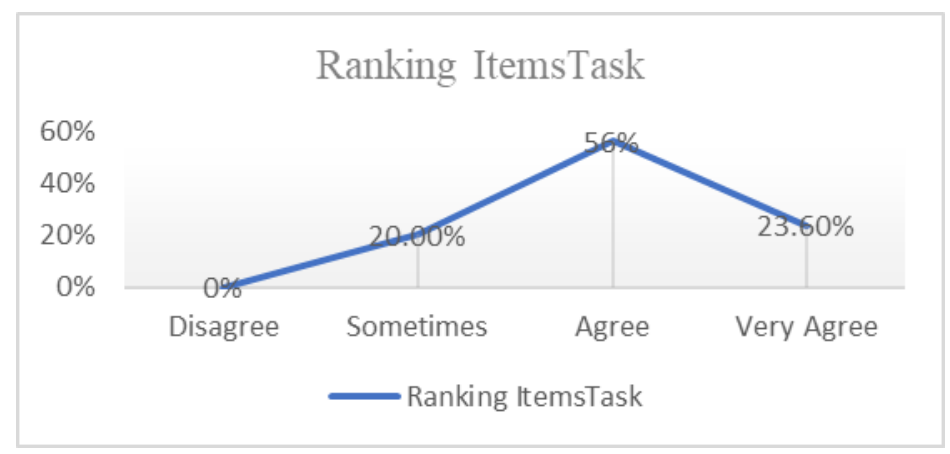

Figure 10. Ranking ItemsTask Needs

Figure 10 concludes that students' answers about the types of the task required in teaching materials on ranking tasks related to specific individual or criteria values, 31 people said it was agreed or $56.4 \%, 13$ people said it was very agreed or $23.6 \%, 11$ people say it does not agree or $20 \%$

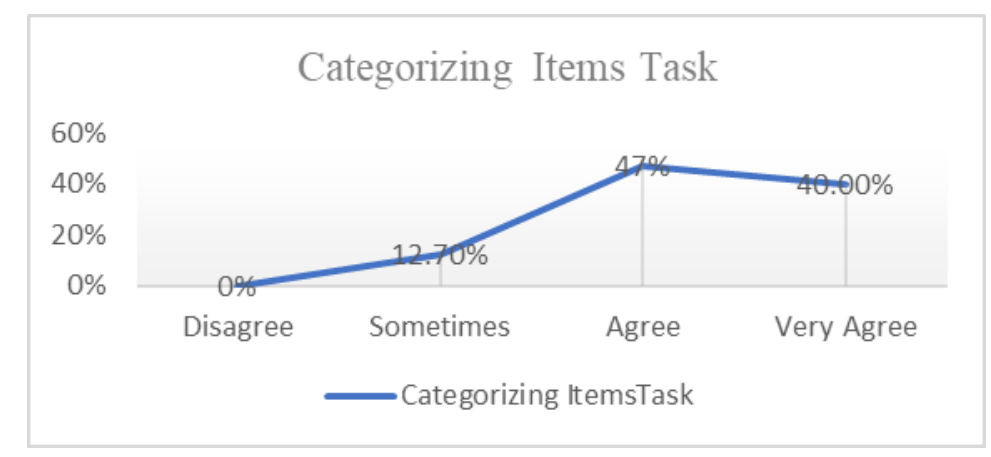

Figure 11. Categorizing Item Task Needs

Figure 11 concludes that students' answers about the types of the task required in teaching materials on categorizing item, 26 people said it was very agreed or $40 \%, 22$ people said it was agreed or $47 \%, 7$ people said it's sometimes or $13 \%$.

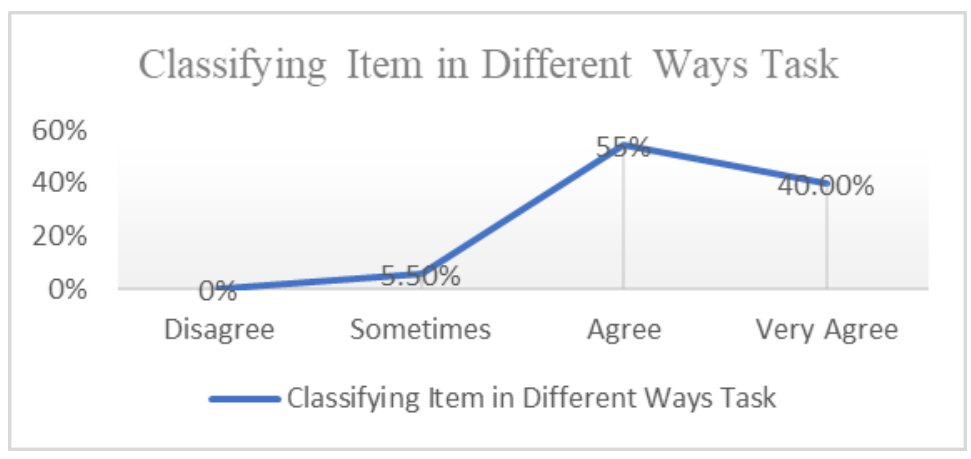


Figure 12. Classifying Item in Different Ways Task Needs

Figure 12 concludes that students' answers about the types of the task required in teaching materials on classifying item in different ways task, 22 people said it was very agreed or $40 \%, 30$ people said it was agreed or $54.5 \%, 3$ people said it's sometimes or $5.5 \%$.

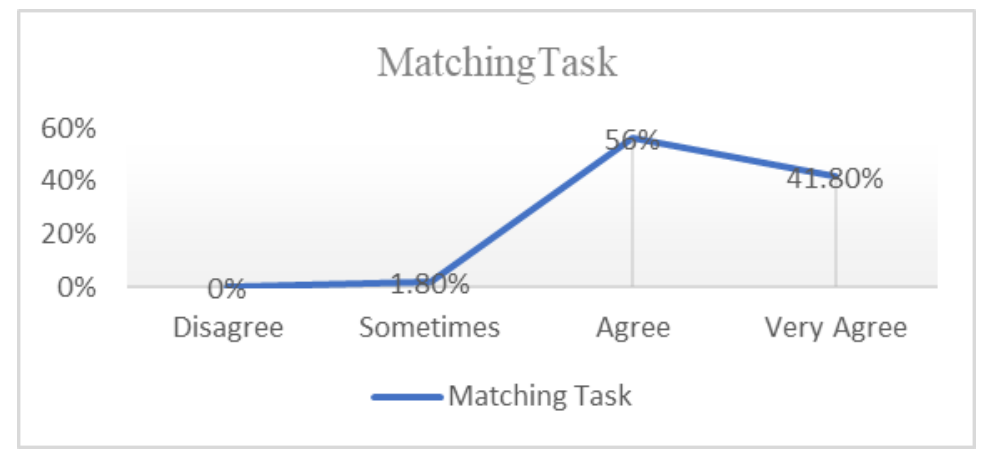

Figure 13. MatchingTask Needs

Figure 13 concludes that students' answers about the types of the task required in teaching materials on matching task, 23 people said it was very agreed or $42.8 \%, 3$ people said it was agreed or $56.4 \%, 1$ people said it's sometimes or $1.8 \%$.

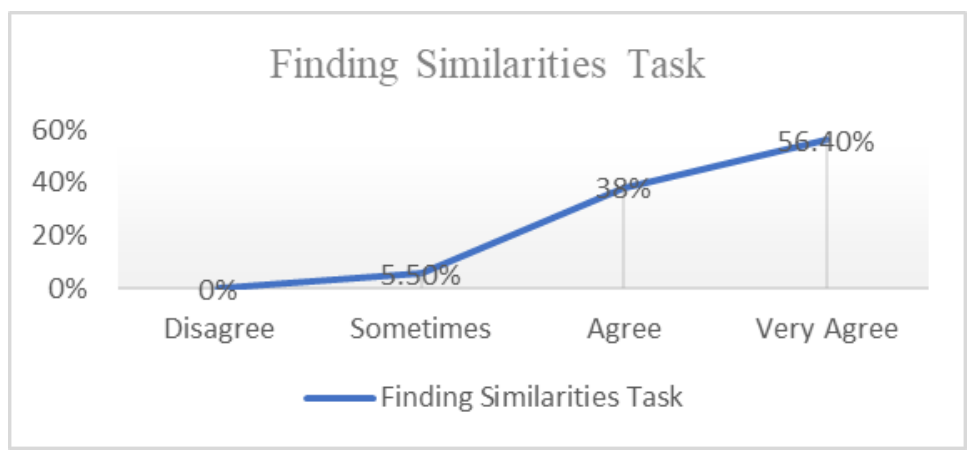

Figure 14. Finding Similarities Task Needs

Figure 14 concludes that students' answers about the types of the task required in teaching materials on finding similarities task, 31 people said it was very agreed or $56.4 \%, 21$ people said it was agreed or $38.2 \%, 3$ people said it's sometimes or $5.5 \%$.

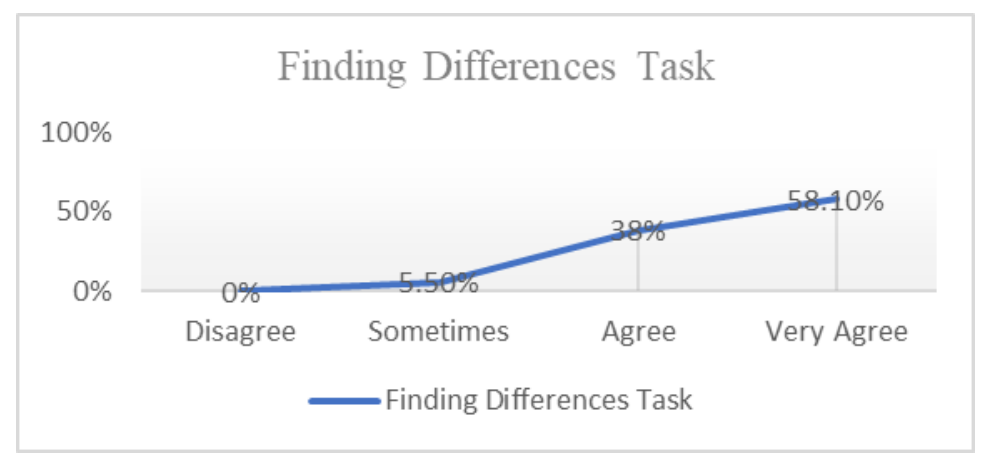


Figure 15. Finding Differences Task Needs

Figure 15 concludes that students' answers about the types of the task required in teaching materials on finding differences task, 31 people said it was very agreed or $58.1 \%, 21$ people said it was agreed or $38.4 \%, 3$ people said it's sometimes or $5.5 \%$.

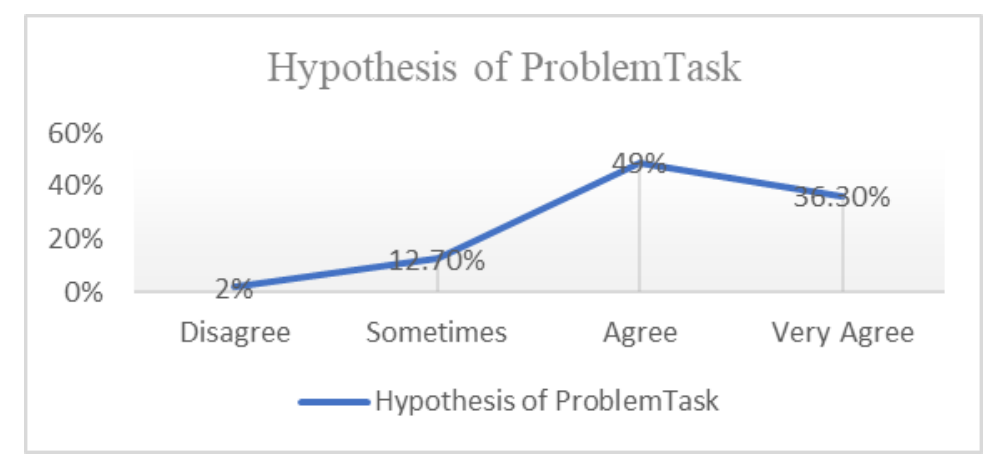

Figure 16. The hypothesis of ProblemTask Needs

Figure 16 concludes that students' answers about the types of task required in teaching materials on hypothesis of problem task, 20 people said it was very agreed or $36.3 \%, 27$ people said it was agreed or $49 \%, 7$ people said it's sometimes or $12.7 \%$, and 1 people said it disagreed or $1.8 \%$

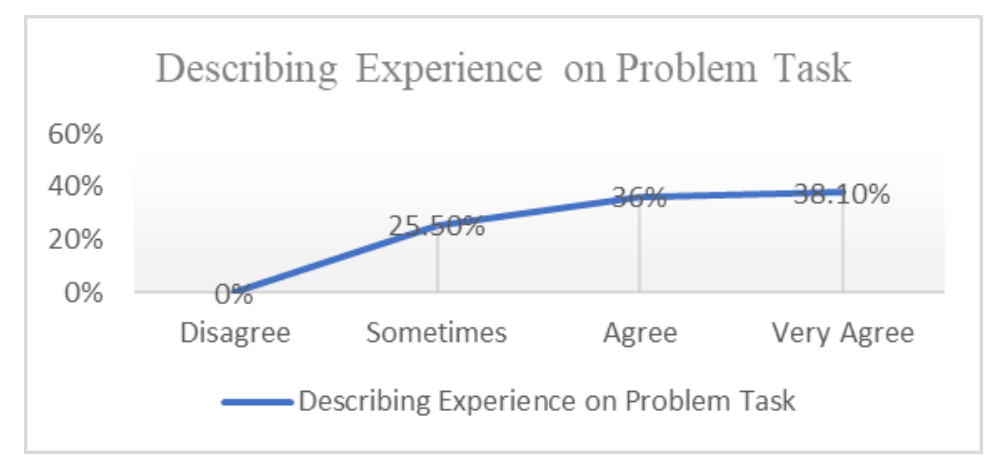

Figure 17. The hypothesis of Problem Task Needs

Graph 17 concludes that students' answers about the types of the task required in teaching materials on describing the experience of problem task, 21 people said it was very agreed or $38.1 \%$, 20 people said it was agreed or $36.4 \%, 14$ people said it's sometimes or $25.5 \%$. 


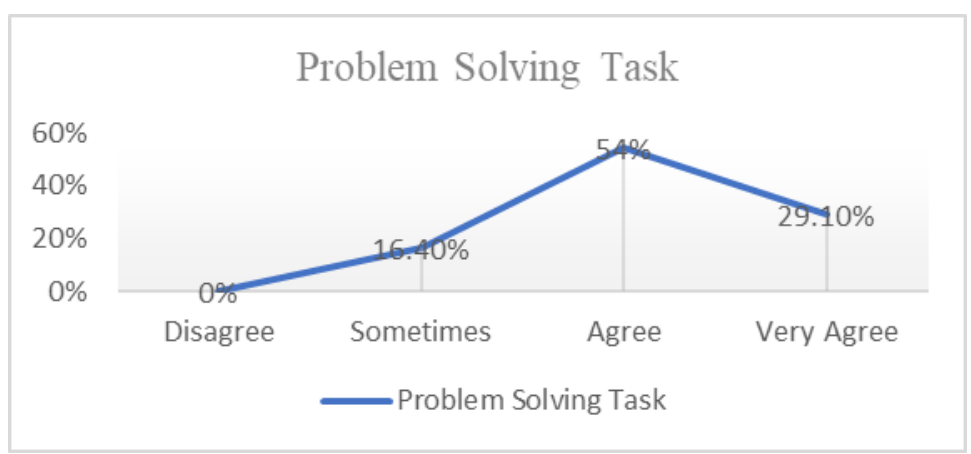

Figure 18. Problem Solving Task Needs

Figure 18 concludes that students' answers about the types of the task required in teaching materials on problem-solving task, 16 people said it was very agreed or $29.1 \%$, 30 people said it was agreed or $54.4 \%, 9$ people said it's sometimes or $25.5 \%$.

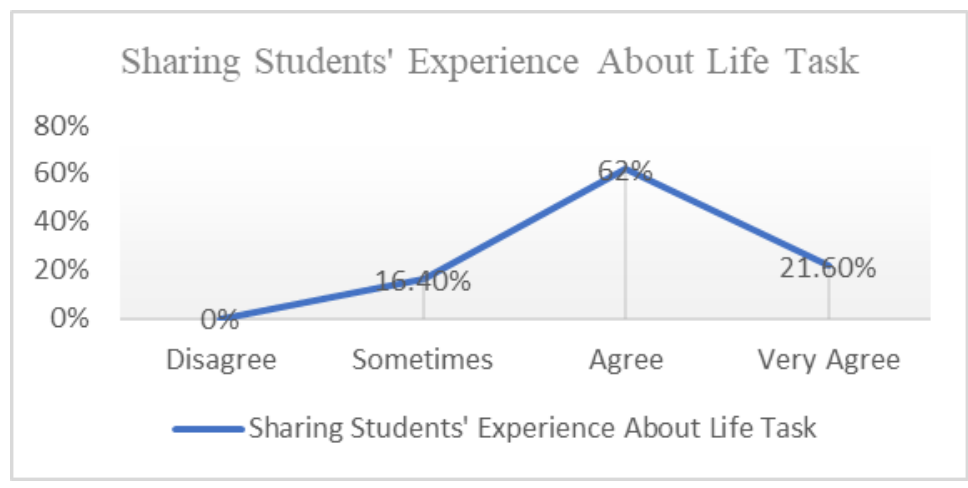

Figure 19. Sharing Students' Experience About Life Task Needs

Figure 19 concludes that students' answers about the types of the task required in teaching materials on sharing students' experience about life task, 12 people said it was very agreed or $62 \%, 34$ people said it was agreed or $21.6 \%, 9$ people said it's sometimes or $16.4 \%$.

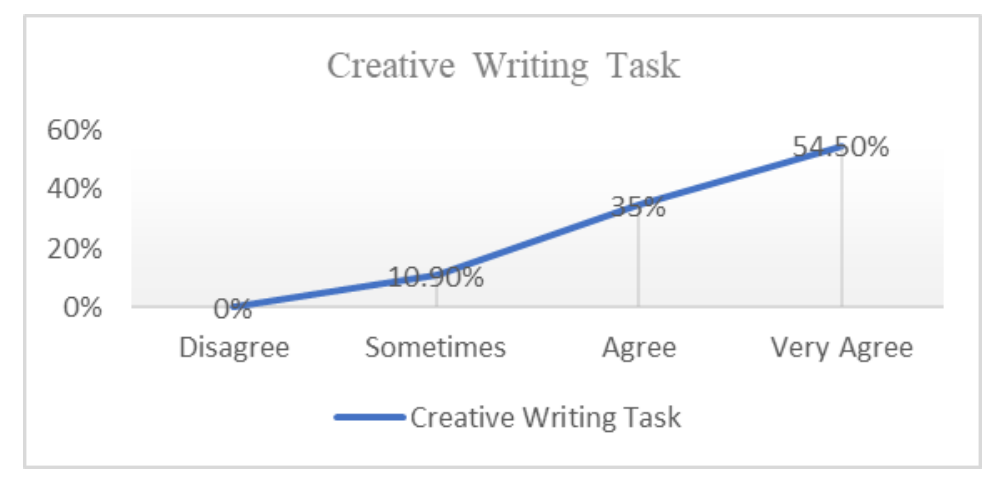

Figure 20. Creative WritingTask Needs

Figure 20 concludes that students' answers about the types of task required in teaching materials on creative writing as freely task, 30 people said it was very agreed or $54.5 \%, 19$ people said it was agreedor $54.6 \%, 6$ people said it's sometimes or $10.9 \%$. 
The result of teacher needs analysis of Arabic guided writing is significant. It can be seen below the table;

Table 1. Types of Tasks Required (Input)

\begin{tabular}{|c|c|c|c|}
\hline & Needs Criteria of the Materials Content & Level Needs & $\%$ \\
\hline \multirow{3}{*}{1} & \multirow{3}{*}{$\begin{array}{l}\text { The material must be related to the experiences and } \\
\text { circumstances of students }\end{array}$} & Very Necessary & $50 \%$ \\
\hline & & Necessary & $50 \%$ \\
\hline & & Not Necessary & $0 \%$ \\
\hline \multirow{3}{*}{2} & \multirow{3}{*}{$\begin{array}{l}\text { Material for Arabic writing requires an explanation about } \\
\text { the task of making a list }\end{array}$} & Very Necessary & $50 \%$ \\
\hline & & Necessary & $50 \%$ \\
\hline & & Not Necessary & $0 \%$ \\
\hline \multirow{3}{*}{3} & \multirow{3}{*}{$\begin{array}{l}\text { Material for Arabic writing requires an explanation about } \\
\text { the comparing task }\end{array}$} & Very Necessary & $50 \%$ \\
\hline & & Necessary & $0 \%$ \\
\hline & & Not Necessary & $50 \%$ \\
\hline \multirow{3}{*}{4} & \multirow{3}{*}{$\begin{array}{l}\text { Material for Arabic writing requires an explanation about } \\
\text { the ordering and sorting task }\end{array}$} & Very Necessary & $50 \%$ \\
\hline & & Necessary & $0 \%$ \\
\hline & & Not Necessary & $50 \%$ \\
\hline \multirow{3}{*}{5} & \multirow{3}{*}{$\begin{array}{l}\text { Material for Arabic writing requires an explanation about } \\
\text { the problem-solving task }\end{array}$} & Very Necessary & $100 \%$ \\
\hline & & Necessary & $0 \%$ \\
\hline & & Not Necessary & $0 \%$ \\
\hline \multirow{3}{*}{6} & \multirow{3}{*}{$\begin{array}{l}\text { Material for Arabic writing requires an explanation about } \\
\text { the sharing personal experiences task }\end{array}$} & Very Necessary & $100 \%$ \\
\hline & & Necessary & $0 \%$ \\
\hline & & Not Necessary & $0 \%$ \\
\hline
\end{tabular}

Table 1 can be concluded that there are six categories to know the teacher's needs in developing Arabic guided writing material. The material must be related to the experiences and circumstances of students is necessary and very necessary (50\%). This percentage is the same as the second category that material for Arabic writing requires an explanation about the task of making a list. While 50\% teacher think that material for Arabic writing requires an explanation about the comparing task is not necessary as well as the fourth category. The fifth and sixth category is necessary (100\%). 
Table 2. Type of Task Required (Content Focus)

\begin{tabular}{|c|c|c|c|}
\hline & Needs Criteria of the Materials Content & Level Needs & $\%$ \\
\hline \multirow{3}{*}{1} & \multirow{3}{*}{$\begin{array}{l}\text { Teaching material developed needs to have the task of } \\
\text { sharing knowledge and experience with friends }\end{array}$} & Very Necessary & $50 \%$ \\
\hline & & Necessary & $50 \%$ \\
\hline & & Not Necessary & $0 \%$ \\
\hline \multirow{3}{*}{2} & \multirow{3}{*}{$\begin{array}{l}\text { Teaching material developed needs to have the task of } \\
\text { finding facts from books }\end{array}$} & Very Necessary & $50 \%$ \\
\hline & & Necessary & $50 \%$ \\
\hline & & Not Necessary & $0 \%$ \\
\hline \multirow{3}{*}{3} & \multirow{3}{*}{$\begin{array}{l}\text { Teaching material that is developed needs to have the task } \\
\text { of sequencing actions or events in a logical or } \\
\text { chronological order }\end{array}$} & Very Necessary & $50 \%$ \\
\hline & & Necessary & $0 \%$ \\
\hline & & Not Necessary & $50 \%$ \\
\hline \multirow{3}{*}{4} & \multirow{3}{*}{$\begin{array}{l}\text { Teaching material that is developed needs to have ranking } \\
\text { tasks that relate to individual values or specific criteria }\end{array}$} & Very Necessary & $50 \%$ \\
\hline & & Necessary & $0 \%$ \\
\hline & & Not Necessary & $50 \%$ \\
\hline \multirow{3}{*}{5} & \multirow{3}{*}{$\begin{array}{l}\text { Teaching materials that are developed need to have the task } \\
\text { of categorizing or grouping according to their categories }\end{array}$} & Very Necessary & $100 \%$ \\
\hline & & Necessary & $0 \%$ \\
\hline & & Not Necessary & $0 \%$ \\
\hline \multirow{3}{*}{6} & \multirow{3}{*}{$\begin{array}{l}\text { Teaching material developed needs to have the task of } \\
\text { classifying or differentiating things }\end{array}$} & Very Necessary & $100 \%$ \\
\hline & & Necessary & $0 \%$ \\
\hline & & Not Necessary & $0 \%$ \\
\hline \multirow{3}{*}{7} & \multirow{3}{*}{$\begin{array}{l}\text { Teaching material that is developed needs to have a } \\
\text { matchmaking task to identify specific things and to link } \\
\text { them to one another }\end{array}$} & Very Necessary & $100 \%$ \\
\hline & & Necessary & $0 \%$ \\
\hline & & Not Necessary & $0 \%$ \\
\hline \multirow{3}{*}{8} & \multirow{3}{*}{$\begin{array}{l}\text { Teaching material developed needs to have the task of } \\
\text { finding equality }\end{array}$} & Very Necessary & $100 \%$ \\
\hline & & Necessary & $0 \%$ \\
\hline & & Not Necessary & $0 \%$ \\
\hline \multirow{3}{*}{9} & \multirow{3}{*}{$\begin{array}{l}\text { Teaching material developed needs to be tasked to find } \\
\text { differences }\end{array}$} & Very Necessary & $100 \%$ \\
\hline & & Necessary & $0 \%$ \\
\hline & & Not Necessary & $0 \%$ \\
\hline \multirow{3}{*}{10} & \multirow{3}{*}{$\begin{array}{l}\text { Teaching material that is developed needs to have the task } \\
\text { of doing a hypothesis }\end{array}$} & Very Necessary & $100 \%$ \\
\hline & & Necessary & $0 \%$ \\
\hline & & Not Necessary & $0 \%$ \\
\hline \multirow{3}{*}{11} & \multirow{3}{*}{$\begin{array}{l}\text { Teaching material developed needs to have the task of } \\
\text { describing the experience of a problem }\end{array}$} & Very Necessary & $100 \%$ \\
\hline & & Necessary & $0 \%$ \\
\hline & & Not Necessary & $0 \%$ \\
\hline \multirow{3}{*}{12} & \multirow{3}{*}{$\begin{array}{l}\text { Teaching material developed needs to have the task of } \\
\text { comparing alternative solutions to problems }\end{array}$} & Very Necessary & $100 \%$ \\
\hline & & Necessary & $0 \%$ \\
\hline & & Not Necessary & $0 \%$ \\
\hline \multirow{3}{*}{13} & \multirow{3}{*}{$\begin{array}{l}\text { Teaching material developed needs to have the task of } \\
\text { sharing student experiences with friends about social life }\end{array}$} & Very Necessary & $100 \%$ \\
\hline & & Necessary & $0 \%$ \\
\hline & & Not Necessary & $0 \%$ \\
\hline & & Very Necessary & $100 \%$ \\
\hline 14 & $\begin{array}{l}\text { writing freer creative assignments } \\
\text { wation to nave the lask of }\end{array}$ & Necessary & $0 \%$ \\
\hline & & Not Necessary & $0 \%$ \\
\hline
\end{tabular}


Table 2 concluded that teaching material developed from fourteen questions raised, namely teaching material developed needs to have the task of sharing knowledge and experience with friends, the task of finding facts from books, the task of sequencing acts or events in a logical or chronological order, the task of ranking relating to specific individual, there is the task of categorizing or grouping according to its category, the task of classifying something, there is a matchmaking task to identify specific things and to link them to one another, the task of finding similarities, the task of finding differences, the task of doing hypotheses, the task of describing the experience of a problem, the task of comparing alternative problem solving, the task of sharing student experiences with friends about social life, and the task of writing creative assignments more freely. Of all the questions answered by the two lecturers with necessary and very necessary, none of the questions was answered unnecessarily.

The results of data analysis found that the guided writing teaching material needs must be based on the concept of task-based learning. Writing learning activities must be carried out through hands-on practice, it is not learning theoretical concepts. Because writing is process and product oriented. On the question of the type of task needed, it is known that the material needs to be designed according to the student's experience. Therefore, the lecturer must know the student experience map. As for the exercises related to the list of information as supporting data in writing can help students develop writing.

In the concept of guided writing learning content, students are directed to share their knowledge and experiences with colleagues, and students can find facts as supporting data. Thus, students can make writing that has value or sense. This shows that these very tasks need to be included in the development of Arabic guided writing materials. Teachers' ability to address L2 writers' needs were constrained by program policies, lack of common teaching and assessment materials, and professional preparation opportunities. ${ }^{28}$ Textbooks / subject matter are one of the important factors

\footnotetext{
${ }^{28}$ Paul Kei Matsuda, Tanita Saenkhum, and Steven Accardi, "Writing Teachers' Perceptions of the Presence and Needs of Second Language Writers: An Institutional Case Study," Journal of Second Language Writing 22, no. 1 (March 1, 2013): 68-86, accessed May 29, 2019, https://www.sciencedirect.com/science/article/abs/pii/S1060374312000823.
} 
that affect students' motivation in learning. A crucial need for subject matter or textbooks is a romanized or transliterated version to enable students to read textbooks themselves. ${ }^{29}$

Another studied that task-based learning can combine using comic. Task-based language teaching and learning is a general approach to the learning process that is developed in every learning activity. In general, the sequence of learning material in preassignment activities begins by presenting a series of pictures (for example, picture comics) in English about the atmosphere according to the thematic syllabus then students are given the opportunity to hear one (or two) pieces of comic conversation in listening. The Task Phase of Activities, the main activity is an effort to bring an atmosphere of learning truly about the themes raised in accordance with real life activities. At this stage, students are trained to conduct exploratory activities from videos that present real learning situations around them. The final stage or Post-Task Activity specifically aims to develop students' communication skills (Communicate) which include activities that promote continued discussion about the continued communication required by students in any material (for example about good home school activities undertaken related to teachers, parents , etc., greetings, farewells). ${ }^{30}$

Some research findings have shown a comprehension of the Task-Based Language method for example Jeon and Hann ${ }^{31}$ which refers on perceptions about TBLT students and teachers where they learn general English in Korea where their research findings indicate that students have positive perceptions about implementation TBLT. The same thing that have done by Rahman ${ }^{32}$ who have promoted Task-Based Language Learning in secondary schools in India. The different combination has done by Robinson $^{33}$ who have investigated the relationship between TBLT and accuracy, fluency, and complexity. It included the personality traits with the task-based learning.

${ }^{29}$ Ashinida Aladdin, "A Needs Analysis for the Course Materials Design of the Arabic Language Course," International Journal of Social Science and Humanity (2016).

${ }^{30}$ Khoirul Anwar and Yudhi Arifani, "Task Based Language Teaching: Development of CALL," International Education Studies 9, no. 6 (May 29, 2016): 168, accessed December 6, 2019, http://www.ccsenet.org/journal/index.php/ies/article/view/60226.

${ }^{31}$ In-Jae Jeon and Jung-won Hahn, "Exploring EFL Teachers' Perceptions of Task-Based Language Teaching: A Case Study of Korean Secondary School Classroom Practice," Asian EFL Journal2 8 (2006).

${ }^{32}$ M.M. Rahman, "Teaching Oral Communication Skills: A Task-Based Approach,” ESP World 1, no. 27 (2010).

${ }^{33}$ Peter Robinson, “Task- Based Language Learning: A Review of Issues," Language Learning 61 (n.d.): 1-36, accessed December 6, 2019, https://onlinelibrary.wiley.com/doi/abs/10.1111/j.14679922.2011.00641.x. 


\section{Conclusion}

The results of the analysis concluded that the input and content for the development of Arabic guided teaching writing materials are needed. The results of analysis of data obtained from teachers and students indicate that the teaching material of guided Arabic writing should be able to be adapted to the character of learning and the objectives to be achieved as well as the development of increasingly advanced science. The percentage obtained as a whole has been at a percentage level of 50\%. Arabic guided writing material is not only oriented to the process but also product. In the process refers to comprehend Arabic guided writing content and variation of task in steps of activity. Variation of task related with the students' experience. Some activity in this task did individually and group. Moreover, changing of task in each meeting helps students feel less pressure when they study writing skills. Furthermore, the researcher provided source of material that students can access. Implication of research oriented to the material development in Arabic Education Program Study focuses on writing subject. The concept of task in needs analysis implement in guided writing subject. The limitation of the focus research is task without technology. Some task that has given without multimedia and technology. Therefore, for the next research, it can combine using technology in writing learning and multimedia.

\section{Acknowledgment}

The author would like to express his gratitude to the State University of Jakarta specially Language and Art Faculty for funding this research.

\section{References}

Aladdin, Ashinida. "A Needs Analysis for the Course Materials Design of the Arabic Language Course.” International Journal of Social Science and Humanity (2016).

Anwar, Khoirul, and Yudhi Arifani. "Task Based Language Teaching: Development of CALL." International Education Studies 9, no. 6 (May 29, 2016): 168. Accessed December 6 , 2019. http://www.ccsenet.org/journal/index.php/ies/article/view/60226.

Byrnes, Heidi, and Rosa M. Manchon. Task-Based Language Learning Insight from and for L2 Writing. Amsterdam: John Benjamin Publishing Company, 2014.

Chovancová, Barbora. "Needs Analysis And Esp Course Design: Self-Perception Of Language Needs Among Pre-Service Students.” Studies In Logic, Grammar And 
Rhetoric $38 \quad 38$, no. 51 (2014). Accessed April 11, 2018. https://www.degruyter.com/downloadpdf/j/slgr.2014.38.issue-1/slgr-20140031/slgr-2014-0031.pdf.

Cunningsworth, Alan. Choosing Your Coursebook. Heineman: Oxford, 1995.

Dajani, Basma Ahmad Sedki. "Teaching Arabic Language: Towards a New Beginning That Stimulates Creativity." Procedia - Social and Behavioral Sciences 192 (June 24, 2015): 758-763. Accessed May 31, 2018. https://www.sciencedirect.com/science/article/pii/S1877042815035570.

Hasmam, Aisah, and Nik Mohd Rahimi. "Types of Text in Books for Learning Arabic as a Second Language: A Document Analysis." Procedia - Social and Behavioral Sciences 7 (January 1, 2010): 50-56. Accessed June 14, 2019. https://www.sciencedirect.com/science/article/pii/S1877042810020124.

Hismanoglu, Murat, and Sibel Hismanoglu. "Task-Based Language Teaching: What Every EFL Teacher Should Do." Procedia - Social and Behavioral Sciences 15 (January 1, 2011): 46-52. Accessed June 14, 2019. https://www.sciencedirect.com/science/article/pii/S187704281100228X.

Hutchinson, Tom, and Alan Waters. English for Spesific Purposes. Cambridge: Cambridge University Press, 1991.

Iizuka, Takehiro. "Task-Based Needs Analysis: Identifying Communicative Needs for Study Abroad Students in Japan." System 80 (February 1, 2019): 134-142. Accessed December 6 , 2019. https://www.sciencedirect.com/science/article/abs/pii/S0346251X18302021.

Jeon, In-Jae, and Jung-won Hahn. "Exploring EFL Teachers' Perceptions of Task-Based Language Teaching: A Case Study of Korean Secondary School Classroom Practice." Asian EFL Journal2 8 (2006).

Linse, Caroline T. Practical English Language Teaching Young Learners. McGraw Hill, 2005.

Matsuda, Paul Kei, Tanita Saenkhum, and Steven Accardi. "Writing Teachers' Perceptions of the Presence and Needs of Second Language Writers: An Institutional Case Study." Journal of Second Language Writing 22, no. 1 (March 1, 2013): 68-86. Accessed May 2019. https://www.sciencedirect.com/science/article/abs/pii/S1060374312000823.

Nasir, Laraib, Syeda Meenoo Naqvi, and Shelina Bhamani. "Enhancing Students Creative Writing Skills: An Action Research Project." Acta Didactica Napocensia 2, no. 2 (2013).

Nation, I.S.P., and John Macalister. Language Curriculum Design. New York dan London: Routledge Taylor \& Francis Group, 2010.

Nordmark, Marie. "Writing Roles: A Model for Understanding Students' Digital Writing and the Positions That They Adopt as Writers." Computers and Composition 46 
(December 1, 2017): 56-71. Accessed August 29, 2018. https://www.sciencedirect.com/science/article/abs/pii/S8755461516300639.

Nunan, David. Designing Tasks for the Communicative Classroom. Cambridge: Cambridge University Press, 2001.

Parse, Rosemarie Rizzo. Qualitative Inquiry: The Path of Sciencing. New York: NLNs, 2001.

Rahman, M.M. "Teaching Oral Communication Skills: A Task-Based Approach.” ESP World 1, no. 27 (2010).

Richards, Jack C. Curriculum Development in Language Teaching. United State of America: Cambridge University Press., 2001.

Robinson, Peter. "Task- Based Language Learning: A Review of Issues." Language Learning $61 \quad$ (n.d.): 1-36. Accessed December 6, 2019. https://onlinelibrary.wiley.com/doi/abs/10.1111/j.1467-9922.2011.00641.x.

Sabarun, . "Needs Analysis on Developing EFL Paragraph Writing Materials at Kalimantan L2 Learners." English Language Teaching 12, no. 1 (December 24, 2018): $\quad 186 . \quad$ Accessed December 2019. http://www.ccsenet.org/journal/index.php/elt/article/view/0/37905.

Tomlinson, Brian. Developing Materials For Language Teaching Second Edition. New York: Bloomsbury, 2013.

Weigle, Sara Cushing. Assessing Writing. United Kingdom: Cambridge University Press, 2002.

Wekke, Ismail Suardi. "Arabic Learning Material of Higher Education Muslim Community North Sulawesi." Dinamika Ilmu 17, no. 2 (December 4, 2017): 175189. Accessed March 31, 2019. https://journal.iainsamarinda.ac.id/index.php/dinamika_ilmu/article/view/863.

Willis, Jane. A Framework for Task-Based Learning. Italy: Addison Wesley Longman, 1996.

Youn, Soo Jung. "Task-Based Needs Analysis of L2 Pragmatics in an EAP Context." Journal of English for Academic Purposes 36 (November 1, 2018): 86-98. $\begin{array}{llll}\text { Accessed June } & 2019 .\end{array}$ https://www.sciencedirect.com/science/article/pii/S147515851830184X.

Yundayani, Audi, Emzir Emzir, and Zainal Rafli. "Need Analysis: The Writing Skill Instructional Material Context For Academic Purposes." English Review: Journal of English Education 6, no. 1 (December 23, 2017): 59. Accessed December 6, 2019. https://journal.uniku.ac.id/index.php/ERJEE/article/view/771.

"Jeremy Harmer-The Practice of English Language Teaching with DVD (4th Edition) (Longman Handbooks for Language Teachers)-Pearson Longman ELT (2007).Pdf," n.d. 